\title{
A szabadalombitorlás miatt elrendelt ideiglenes intézkedéssel okozott kárért való helytállási kötelezettség ${ }^{1}$
}

\section{Appropriate Compensation for a Wrongfully-Issued Preliminary Injunction Ordered in a Patent Infringement Dispute}

A TRIPS és a Jogérvényesítési Irányelv szabályozza az ideiglenes intézkedéssel okozott kárért való helytállási kötelezettséget, amikor megállapítják, hogy nem történt szellemi tulajdonjogi jogsértés. Ennek értelmezését kérte a Fővárosi Törvényszék. A jelen cikk a fötanácsnok indítványát ismerteti.

Kulcsszavak: szellemi tulajdon, ideiglenes intézkedés, Jogérvényesítési Irányelv, helytállási kötelezettség

TRIPS and the Enforcement Directive provide for appropriate compensation for a wrongfully-issued preliminary injunction in IP dispute. The Metropolitan Court of Budapest commenced preliminary ruling procedure on interpreting this provision. This article presents the opinion of the Advocate General.

Keywords: IP rights, preliminary injunction, enforcement directive, compensation 


\section{Bevezetés}

A Bayer-ügyben² az Európai Unió Bíróságának (a továbbiakban: Bíróság) a szellemi tulajdonjogok érvényesítéséről szóló irányelv³ (a továbbiakban: Jogérvényesítési Irányelv) rendelkezését kell értelmeznie a Fővárosi Törvényszék megkeresése ${ }^{4}$ alapján. Az alapeljárás tárgya az, hogy ha a szabadalombitorlási eljárásban a bíróság ideiglenes intézkedéssel eltiltást rendel el, és később az intézkedés jogalapját veszti, például azért, mert a jogi oltalmat (jelen esetben szabadalmi oltalom) megsemmisítik, milyen felelősség/helytállási kötelezettség terheli a kérelmezőt. Más szóval: az eltiltással okozott kárt melyik félre kell telepíteni. Az ügy lényege az eljárási eszközökkel biztosított, anyagi jogi hatású fegyveregyenlőség.

A Bíróság 2019. január 8-án tartott tárgyalást, Pitruzella főtanácsnok 2019. április 11-én hozta meg az indítványát. A Bíróság 2019. szeptember 12-én fogja az ítéletét kihirdetni. A jelen cikk a főtanácsnok indítványát ismerteti az EU jog értelmezéséről.

\section{Tényállás}

A Bayer 2000-ben szabadalmi bejelentést tett egy fogamzásgátló hatóanyagot tartalmazó gyógyszerkészítménnyel kapcsolatos találmányra. A Magyar Szabadalmi Hivatal 2010. októberben adott szabadalmat a találmányra.

Már az oltalom megadása előtt, 2009-ben két generikus gyógyszergyártó, a Richter Gedeon Nyrt. és az Exeltis Magyarország Kft. megkezdte olyan készítmények magyarországi forgalmazását, amelyek a Bayer szerint a szabadalmába ütköznek. A találmány a közzétételt követően ugyan ideiglenes oltalom alatt állt [Szt. ${ }^{5}$ 12. § (2) bek.], a Bayer csak azt követően tudott ideiglenes intézkedés iránti kérelmet előterjeszteni, hogy a szabadalmat megadták.

A Fővárosi Törvényszék a rPp. ${ }^{6}$ 156. § és a Szt. 104. § alapján 2011. júliusban ideiglenes intézkedéssel kötelezte a generikus gyártókat a forgalmazás abbahagyására. A bíróság az ideiglenes intézkedést a Bayer általi biztosítékadáshoz kötötte. Az ideiglenes intézkedés előzetesen végrehajtható, a generikus gyártók a termékeket a piacról visszavonták.

A generikusok fellebbezései nyomán a Fővárosi Ítélőtábla 2011. októberben az ideiglenes intézkedést eljárási hibák miatt ${ }^{7}$ hatályon kívül helyezte. Az új eljárásban az elsőfokú bíróság a Bayer ideiglenes intézkedés iránti kérelmét elutasította, mivel

C-688/17. sz. Bayer Pharma AG-ügy [ECLI:EU:C:2019:324].

Az Európai Parlament és a Tanács 2004/48/EK irányelve (2004. április 29.) a szellemi tulajdonjogok érvényesítéséröl, HL L 157., 2004. 04. 30., 45-86.

3.P.20.998/2017.

1995. évi XXXIII. törvény a találmányok szabadalmi oltalmáról.

1952. évi III. törvény a polgári perrendtartásról.

Fôvárosi Ítélőtábla 8.Pkf.26.503/2011/9 sz. végzése szerint az ideiglenes intézkedés elrendelésének sem anyagi jogi feltételei (a jogsértés valószínűsítettsége), sem pedig eljárásjogi feltételei (különös méltánylást érdemlő jogvédelmi helyzet és kárveszély, továbbá arányosság) nem voltak valószínűsítve, továbbá a biztosíték összegét sem munkálták ki kellőképpen. 
az ekvivalens európai szabadalom megvonása miatt a közérdek (gyógyszerellátás, választék, fogyasztói érdek) szempontjából nem tekintette már arányosnak az eltiltást.

Mindemellett az ideiglenes intézkedés több mint 2 hónapig volt hatályban, amely időszakban a generikus gyártók a termékeiket nem tudták forgalmazni.

A bitorlással szembeni védekezés részeként - a szabadalom megadását követő 2 hónappal - a generikus gyártók megsemmisítési kérelmet nyújtottak be a MSZH-hoz a szabadalom ellen. 2012-ben a Szellemi Tulajdon Nemzeti Hivatala (SZTNH) ${ }^{8}$ a szabadalmat megsemmisítette, visszamenőleges hatállyal, és a határozat a megváltoztatási eljárást követően 2016-ban vált jogerőssé.

A generikus gyártók viszontkeresetben azt kérték, hogy a bíróság a Bayert kötelezze az ideiglenes intézkedéssel okozott kár kiegyenlítésére. A kár elsődlegesen árbevétel-kiesés.

\section{A követelés jogalapja}

A viszontkeresetben előterjesztett követelés jogalapja a rPp. 156. § és a Szt. 104. § (13) bek., ${ }^{10}$ amely előírja, hogy a bíróság az ideiglenes intézkedés elrendelését biztosítékadáshoz kötheti, és a korábbi magyar joggyakorlat ${ }^{11}$ kártalanítási jellegú igénynek tekinti azt az igényt, ha a bíróság által - elrendelésekor jogszerűen - elrendelt ideiglenes intézkedés a szabadalom visszamenőleges megsemmisítése alapján később megdől. A hátrányok megtérítése iránti igény azáltal keletkezik, hogy az ideiglenes intézkedés hatálya alatt a termékek forgalmazásától a bíróság a kérelmezetteket (a perben: alpereseket) a szabadalmas kérelmére jogszerűen eltiltotta. Ebből következően a szabadalmas viseli annak kockázatát, ha az intézkedés utóbb alapját veszti.

A Bayer a kereset elutasítását kérte arra hivatkozással, hogy a generikus gyártók a kárt saját maguk okozták, ennélfogva annak megtérítésére a magyar polgári jogi felelősség szabályai alapján nem jogosultak. A generikus gyártók ugyanis - szándékosan és jogellenesen - jóval a szabadalom megsemmisítése előtt vezették be a piacra a bitorló termékeket. Generikus gyógyszergyártóként tudomással bírtak arról, hogy a Bayer szabadalommal rendelkezik, így a károk elkerülése érdekében a termékek forgalomba hozatalát megelőzően a szabadalmat kellett volna megtámadniuk, és megvárniuk,

A Magyar Szabadalmi Hivatal új neve 2011. január 1-től Szellemi Tulajdon Nemzeti Hivatala.

156. § (1) A bíróság kérelemre ideiglenes intézkedéssel elrendelheti a kereseti kérelemben (viszontkeresetben), illetve az ideiglenes intézkedés iránti kérelemben foglaltak teljesítését, ha ez közvetlenül fenyegető kár elhárítása vagy a jogvitára okot adó állapot változatlan fenntartása, illetve a kérelmező különös méltánylást érdemlő jogvédelme érdekében szükséges, és az intézkedéssel okozott hátrány nem haladja meg az intézkedéssel elérhető előnyöket. A bíróság az ideiglenes intézkedés elrendelését biztosítékadáshoz kötheti. A kérelmet megalapozó tényeket valószínúsíteni kell.

10 Szt. 104. (13) A bíróság az előzetes bizonyítás és - az (5) bekezdés c) pontját és a (6) bekezdést kivéve - az ideiglenes intézkedés elrendelését biztosítékadáshoz kötheti.

(14) Ha az (5) bekezdés c) pontjában, a (6) bekezdésben és a (13) bekezdésben meghatározott esetekben a biztosíték összegéből való kielégítésre jogosult fél igényét az előzetes bizonyítás, illetve az ideiglenes intézkedés tárgyában hozott végzést hatályon kívül helyező határozat, illetve az ítélet (permegszüntető végzés) jogerőre emelkedésétől számított három hónapon belül nem érvényesíti, a letevő a biztosíték visszaadását kérheti a bíróságtól.

11 Fővárosi Ítélőtábla 8.Pf.20.845/2007/5 végzése. 
hogy a megsemmisítési eljárásban legalább első fokon döntést hozzanak. A Bayer úgy véli, hogy a kártérítést kérelmező felek felelősek a kár bekövetkezéséért. A rPtk. 4 . § (4) bekezdése szerint: „Saját felróható magatartására előnyök szerzése végett senki sem hivatkozhat."

\section{Az uniós jogi háttér: a Jogérvényesítési Irányelv}

A Jogérvényesítési Irányelv (22) preambulumbekezdése kimondja: „[E]lengedhetetlen az olyan ideiglenes intézkedések biztosítása, amelyek a jogsértések azonnal megszüntetését szolgálják az ügyre vonatkozó érdemi döntés bevárása nélkül, a védelem jogainak tiszteletben tartása mellett, biztosítva az ideiglenes intézkedések arányosságát a kérdéses ügy sajátosságainak megfelelően és azon garanciákat, amelyek szükségesek a megalapozatlan kérelemből adódóan az alperes oldalán felmerült költségek és okozott kár fedezésére. Ezen intézkedések különösen akkor indokoltak, ha a késedelem helyrehozhatatlan kárt okozna a szellemi tulajdonjog jogosultjának."

A Jogérvényesítési Irányelv 9. cikk (7) bek. szerint amennyiben az ideiglenes intézkedéseket megszüntetik, vagy a felperes cselekménye vagy mulasztása folytán hatályukat vesztik, vagy amennyiben a továbbiakban megállapítják, hogy nem történt szellemi tulajdonjogi jogsértés, vagy annak veszélye nem állt fenn, a bíróságok az alperes kérelmére elrendelik, hogy a felperes nyújtson megfelelő kártérítést az alperes számára az ilyen intézkedések által okozott károkért.

A Jogérvényesítési Irányelv szövege azonos a Kereskedelmi Világszervezet (WTO) keretében kötött TRIPS ${ }^{12}$ megállapodás 50. cikkének (7) bekezdésével.

A Jogérvényesítési Irányelv magyar szövege a generikusok álláspontja szerint, amellyel az Igazságügyi Minisztérium is egyetértett, téves fordítást tartalmaz és helytelenül használja a „megfelelő kártérítés” kifejezést, amely helyesen „megfelelő kártalanítás” lenne. A Jogérvényesítési Irányelv különböző nyelvi változatai is alátámasztják a helytelen fordítást. A kártérítés szót eltérő tartalommal használja a Jogérvényesítési Irányelv: a 13. cikkhez kapcsolódó cím: „Kártérítés”, amely szerint „a tagállamok biztosítják, hogy az illetékes bíróságok a sértett fél kérelmére elrendeljék, hogy a jogsértő, aki tudta, vagy kellő gondosság mellett tudnia kellett volna, hogy jogsértést valósít meg, a jogosult számára a jogsértés folytán elszenvedett tényleges kárnak megfelelő kártérítést fizessen”. Ugyanezen cikk címe az angol szövegben: „Damages”, a német szövegben: „Schadenersatz”, a francia szövegben: „Dommages-intérêts”. Látható, hogy a Jogérvényesítési Irányelv elfogadáskori szövegeiben a 13. cikk eltérő szóhasználatot alkalmaz, mint a 9. cikk (7) bekezdése (appropriate compensation, angemessenen Ersatz, un dédommagement approprié). Ennek ellenére a magyar szövegben mind a 9. cikk (7) bekezdésben, mind a 13. cikkben a kártérítés szó szerepel.

12 A Kereskedelmi Világszervezetet (WTO) létrehozó, 1994. április 15-én Marrakeshben megkötött, és az 94/800/EK tanácsi határozattal jóváhagyott egyezmény 1. C) mellékletét képező, a szellemi tulajdonjogok kereskedelmi vonatkozásairól szóló megállapodás (a továbbiakban: TRIPS megállapodás). Magyarországon kihirdette: az 1998. évi IX. törvény az Általános Vám- és Kereskedelmi Egyezmény (GATT) keretében kialakított, a Kereskedelmi Világszervezetet létrehozó Marrakesh-i Egyezmény és mellékleteinek kihirdetéséről. 
A különbségtétel jelentősége, amint a Fővárosi Törvényszék is jelezte, hogy a magyar polgári jogi jogdogmatika különbséget tesz a jogellenességen és felróhatóságon alapuló kártérítési felelősség és a jogszerúen okozott kár ellentételezése fejében járó kártalanítás között. A magyar Igazságügyi Minisztérium az Európai Unió Tanácsa Főtitkárságához a magyar nyelvű változat módosítása iránti kérelmet nyújtott be. A fordítás helyesbítése nem történt meg.

A Fővárosi Törvényszék két kérdésben találta szükségesnek megkeresni a Bíróságot.

\section{A Fővárosi Törvényszék első kérdése}

Az alapeljárásban vita volt a felek között, hogy szükséges-e a Bíróság megkeresése. Hasonló tényállás mellett a Cour d'appel de Paris ${ }^{13}$ 2014-ben elutasította az elózetes döntéshozatal iránti kérelmet, és megállapította, hogy az Irányelv egyértelmű abban (acte claire), hogy kártalanítás jár nemcsak abban az esetben, ha a bitorlás hiányát állapítják meg, hanem akkor is, ha a szabadalom megsemmisítésre kerül, és a kártalanítás magában foglalja az eltiltás időtartama alatt elmaradt hasznot is.

A Fővárosi Törvényszék első kérdése arra keresi a választ, hogy a 9. cikk (7) bekezdését úgy kell-e értelmezni, hogy az csak a kártérítéshez való jogot biztosítja az alperes számára, e jog tartalmát azonban nem határozza meg kimerítően, hanem a tagállamokra bízza az e jog gyakorlásával kapcsolatos feltételek és részletes szabályok, valamint a kártérítés mértékének meghatározását.

A főtanácsnok elemzésének alapja a TRIPS Megállapodás. Ennek háttere, hogy a Jogérvényesítési Irányelv 9. cikk (7) bekezdésének szövege szóról szóra megismétli a TRIPS Megállapodás 50. cikkének (7) bekezdését. A Bíróság korábban megállapította, hogy „a TRIPS-megállapodás rendelkezései az uniós jogrend szerves részét képezik, és e jogrend értelmében a Bíróság hatáskörrel rendelkezik az említett megállapodás előzetes döntéshozatal keretében történő értelmezésére". ${ }^{14}$ A TRIPS-megállapodás két alapvető célkitűzést követ: egyrészt gondoskodni kell arról, hogy a szellemi tulajdonjog megsértése esetén hatékony eljárások álljanak a jogtulajdonosok rendelkezésére, másrészt biztosítaniuk kell, hogy ezeket az eljárásokat oly módon alkalmazzák, hogy ne gátolják a kereskedelmet és biztosítékot nyújtsanak a velük való visszaéléssel szemben. A TRIPS 50. cikk (7) bekezdése a kötelezettséget nem részletekbe menően határozza meg, hanem az elérendő célt jelzi, nagy mozgásteret biztosítva a tagállamoknak a nemzeti jogban való végrehajtás során.

A főtanácsnok a TRIPS elemzését követően áttért a Jogérvényesítési Irányelv 9. cikk (7) bekezdés céljának értelmezésére. Amint azt a Bíróság a Diageo Brands-ítéletében ${ }^{15}$ kimondta, a Jogérvényesítési Irányelv a szellemi tulajdonjogok védelmének biztosítására szolgáló jogorvoslatokat az azokhoz szorosan kapcsolódó kártérítési keresetek egészítik

\footnotetext{
13 Biogaran v. Laboratoires Negma, Laboratoire Medidom, Cour d’appel de Paris, 2014 január 31., № 12/05485, Elérhető: www.eplawpatentblog.com/eplaw/2014/04/fr-biogaran-v-laboratoires-negmadamages.html\#more (A letöltés dátuma: 2019. 07. 01.)

14 Lásd többekközött: C-431/05.sz. Merck Genéricos-Produtos Farmacêuticos-ügy [ECLI:EU:C:2007:496], az ítélet 31. pontja; C-180/11. sz. Bericap-ügy [ECLI:EU:C:2012:717], az ítélet 67. pontja).

15 C-681/13. sz. Diego Brands-ügy [ECLI:EU:C:2015:471], az ítélet 74. pontja.
}

Európai Tükör 2019/3. 
ki. Míg a 9. cikk (1) bekezdése a szellemi tulajdonjogot fenyegető sérelem megakadályozására irányuló ideiglenes intézkedésekről rendelkezik, ugyanezen cikk (7) bekezdése olyan intézkedéseket ír elő, amelyek lehetővé teszik, hogy az alperes kártérítést kérjen abban az esetben, ha a későbbiekben megállapítják, hogy nem történt szellemi tulajdonjogi jogsértés, vagy annak veszélye nem állt fenn. Amint a (22) preambulumbekezdésből kitűnik, ez olyan garanciának minősül, amelyet az uniós jogalkotó az általa előírt gyors és hatékony ideiglenes intézkedések ellensúlyozására tartott szükségesnek. $\mathrm{Az}$ alapügybelihez hasonló eljárás tehát a 9. cikk (7) bekezdésének hatálya alá tartozik. A Jogérvényesítési Irányelv alapján a tagállomoknak olyan mechanizmust kell bevezetni, amely az eltiltott gyártó számára lehetővé teszi, hogy az ideiglenes intézkedés miatt elszenvedett kárért bírósági úton megfelelő kártérítést kaphasson az e rendelkezésben meghatározott esetekben.

A fötanácsnok hangsúlyozta, hogy a Jogérvényesítési Irányelv alapján nem lehet megállapítani, hogy az valamely meghatározott felelősségi rendszer választását is megkövetelné a tagállamoktól. A Jogérvényesítési Irányelv nem irányul az ideiglenes intézkedés végrehajtásával okozott károkkal kapcsolatos felelősségre vonatkozó nemzeti rendelkezések teljes körű közelítésére. Az unió nem törekszik a kérelmező helytállására vonatkozó szabályok harmonizálására, és a tagállamoknak széles körű mérlegelési mozgásteret hagy. ${ }^{16}$

A főtanácsnok megállapította, hogy az EU eleget tett a szellemi tulajdonjogok érvényesítésének biztosítására vonatkozóan a TRIPS-megállapodásban előírt jogalkotási kötelezettségének. Noha a Jogérvényesítési Irányelv célja, amint azt a (10) preambulumbekezdése is kimondja, a nemzeti jogszabályok egymáshoz való közelítése egy magas, egyenértékű és egységes védelmi szint biztosítása érdekében, mindazonáltal ezen a téren nem végez teljes körü harmonizációt, hiszen annak célja nem a szellemi tulajdonjogok valamennyi vonatkozásának szabályozása. A 9. cikk (7) bekezdésében előírt „megfelelő kártalanítás"17 fogalmát nem lehet úgy értelmezni, hogy az valamely meghatározott felelősségi rendszert jelölne ki. A „megfelelő” melléknév alkalmazása a ténylegesen elszenvedett károkra és az eset körülményeire tekintettel az alperesnek járó kártérítés megfelelőségére vonatkozó értékelés előírására szorítkozik. Ez az értelmezés következik a Jogérvényesítési Irányelv (17) preambulumbekezdéséből is, miszerint „[a]z ezen irányelvben foglalt intézkedéseket, eljárásokat és jogorvoslatokat minden egyes esetben úgy kell meghatározni, hogy az figyelembe vegye az adott eset jellemző vonásait, ideértve az egyes szellemi tulajdonjogok sajátosságait".

A főtanácsnok azt a következtetést vonja le, hogy a tagállomoknak lehetővé kell tenniük, hogy bármely ideiglenes intézkedés miatt elszenvedett kárért bírósági úton megfelelő kártérítést lehessen igényelni, de az Irányelv nem irányul az ideiglenes intézkedéssel okozott károkkal kapcsolatban a nemzeti jog teljes körű közelítésére. A tagállamoknak kell meghatározniuk az ilyen kár megtérítéséhez való jogot szabályozó anyagi jogi szabályokat, amelyekben tekintettel kell lenni arra, hogy lehetővé tegyék minden elszenvedett kár megfelelő megtérítését, de nem tartják vissza a szellemi tulajdonjog jogosultját attól, hogy ideiglenes intézkedés elrendelését kérelmezze.

A főtanácsnoki indítvány 41. pontja.

A főtanácsnok indítványában itt a „kártalanítás” kifejezést használja.

Európai Tükör 2019/3. 


\section{A Fôvárosi Törvényszék második kérdése}

A Fővárosi Törvényszék második kérdése arra irányul, hogy az irányelvvel ellentétes-e valamely tagállam polgári jogi szabályainak olyan alkalmazása, amelynek értelmében a nemzeti bíróság az utólag megalapozatlanná vált ideiglenes intézkedéssel okozott kár megtérítésére irányuló keresetet elutasítja, ha a kár amiatt következett be, hogy a generikus gyártó nem úgy járt el, ahogy „az az adott helyzetben általában elvárható”, más szóval: ha a termékeket a szabadalom érvényességének előzetes vitatása nélkül hozta forgalomba, illetve anélkül hogy megvárta volna, hogy a szabadalmat - legalább elsőfokon - megsemmisítsék.

A főtanácsnok szerint az irányelv szövegével, mind a céljaival ellentétes lenne e rendelkezés olyan értelmezése, amely szerint tagállamok az alperes bármely kártérítéshez való jogát kizárhatják abban az esetben, ha az alperes azon szabadalom megsértésével lépett a piacra, amelynek védelme érdekében az ideiglenes intézkedéseket elrendelték, és nem várta meg, hogy azt előzőleg megsemmisítsék.

A Jogérvényesítési Irányelv két célkitűzés között teremt egyensúlyt: egyrészt a szellemi tulajdonjogok jogosultjai érdekeinek védelme, másrészt a jogszerű kereskedelem indokolatlan korlátozásoktól való megóvása. Ha a szabadalmas mentesülne az ideiglenes intézkedésekkel okozott kár megtérítésére vonatozó kötelezettség alól pusztán arra hivatkozással, hogy a szabadalom az intézkedés elrendelésének időpontjában még érvényes volt, ez a fenti célkitűzésekbe ütközne, és az ideiglenes intézkedések visszaélésszerú igénybevételére ösztönözhetne.

A fenti megfontolások azonban nem jelentik azt, hogy az alapeljárásbelihez hasonló helyzetben az alperes magatartását - különösen azt a tényt, hogy a piacra bitorló termékeket vezetett be, anélkül hogy a szóban forgó szellemi tulajdoni jogcímet előzetesen megtámadta vagy tartalmi szempontból kétségbe vonta volna - a nemzeti bíróság ne vehetné figyelembe.

A főtanácsnok indítványából levonható az a következtetés, hogy míg az előző kérdésre adott válasz szerint a tagállami anyagi jogi szabályok széles körben érvényesülnek, a második kérdésre adott válaszból kiderül, hogy ezt az autonómiát korlátozza az Irányelv céljának érvényre juttatása.

\section{Összefoglalás}

A főtanácsnok - követve a Fővárosi Törvényszéket - alappal indult ki abból, hogy a kártérítési jog nemzeti szabályai nem alkalmazhatók, mert nem jogellenes károkozásról van szó, hiszen a bíróság rendeli el a szabadalmas valószínűsítése alapján az ideiglenes intézkedést. Ha a szabadalmas mentesülhetne arra hivatkozással, hogy a másik fél is közrehatott a kár bekövetkezésében, az esetek nagy részében ez a kár megtérítésének kizárását eredményezné.

Mindenesetre a főtanácsnok nyitva hagyja azt, hogy ha a generikus gyártó az úgynevezett „kockázatos” piacra lépést választotta (üzleti nyelvben: risk at launch), ez a megfelelő kártérítéshez való jogának kizárását ugyan nem jelenti, de a nemzeti bíróság ezt a magatartást, más releváns körülményekkel együtt - mint például a szabadalom 
és a piac jellemzői - figyelembe veheti az eltiltott gyártóknak nyújtandó megtérítés meghatározásakor, amelynek méltányosnak és igazságosnak kell lennie. Érdekes lesz majd, hogy a Bíróság ítélete követi-e a Főtanácsnokot, vagy ez utóbbi kérdést megválaszolatlanul hagyja.

A Bíróságnak arról kell döntenie, hogy az ideiglenes intézkedés elrendelésének kockázatát a kérelmezőnek mennyiben kell viselnie, amely helytállási kötelezettség nem függ a felek tudattartamától.

\section{Felhasznált irodalom}

BACHER Vilmos - FALUDI Gábor (2005): Jogérvényesítés a szellemitulajdon-jogok területén. Iparjogvédelmi és Szerzői Jogi Szemle. Elérhető: www.sztnh.gov.hu/hu/ kiadv/ipsz/200504/01-bacher.html (A letöltés dátuma: 2019. 07. 01.)

Cour d'appel de Paris ítélete a Biogaran v. Laboratoires Negma, Laboratoire Medidom ügyben, № 12/05485

GervaIS, Daniel (2012): The TRIPS Agreement: Drafting History and Analyses. 4. kiadás. Oxford.

\section{Internetes forrás}

www.eplawpatentblog.com/eplaw/2014/04/fr-biogaran-v-laboratoires-negma-damages. html\#more (A letöltés dátuma: 2019. 07. 01.)

\section{Jogforrások}

1998. évi IX. törvény az Általános Vám- és Kereskedelmi Egyezmény (GATT) keretében kialakított, a Kereskedelmi Világszervezetet létrehozó Marrakesh-i Egyezmény és mellékleteinek kihirdetéséről

1995. évi XXXIII. törvény a találmányok szabadalmi oltalmáról 1952. évi III. törvény a polgári perrendtartásról

Az Európai Parlament és a Tanács 2004/48/EK irányelve (2004. április 29.) a szellemi tulajdonjogok érvényesítéséről, HL L 157., 2004. 04. 30., 45-86. 